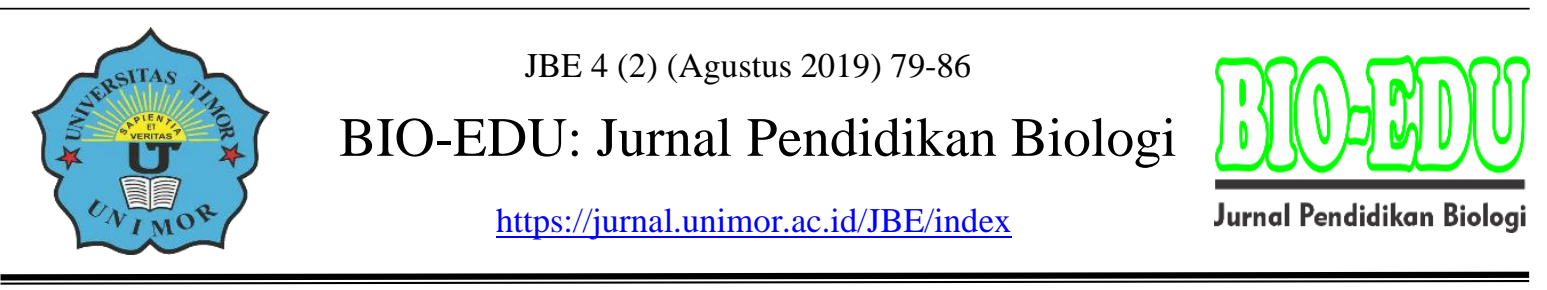

\title{
Pengaruh Kemampuan Awal terhadap Hasil Belajar IPA Biologi Peserta Didik Kelas VIII SMP Negeri 1 Kaledupa Kabupaten Wakatobi
}

\author{
Muhammad Amran Shidik \\ Program Studi Pendidikan Biologi, Universitas Timor \\ Email: muh.amranshidik@gmail.com
}

DOI: https://doi.org/10.32938/jbe.v4i2.395

\begin{abstract}
Abstrak
Penelitian ini bertujuan unutk mengetahui pengaruh kemampuan awal terhadap hasil belajar IPA Biologi peserta didik kelas VIII SMP Negeri 1 Kaledupa. Penelitian ini dapat membantu para pendidik dalam menyusun bahan ajar untuk peserta didik sebelum memulai pembelajaran. Jenis penelitian yang digunakan dalam penelitian ini adalah ex post facto. Populasi pada penelitian ini adalah seluruh kelas VIII SMP Negeri 1 Kaledupa dengan jumlah 3 kelas, sedangkan sampel diperoleh 1 kelas dengan menggunakan purposive sampling. Instrumen untuk mengumpulkan data menggunakan instrument tes baik untuk kemampuan awal peserta didik maupun untuk hasil belajar. Haisl penelitian menunjukkan bahwa terdapat pengaruh kemampuan awal terhadap hasil belajar IPA Biologi peserta didik kelas VIII SMP Negeri 1 Kaledupa. Hal ini berdasarkan hasil uji hipotesis menggunakan analisis regresi sederhana diperoleh nilai signifikansi sebesar 0,004 $<0,05$. Selain itu, dari tabel analisis regresi sederhana diketahui pula bahwa koefisien regresi kemampuan awal sebesar 0,764 yang menyatakan bahwa setiap penambahan $1 \%$ skor kemampuan awal, maka skor hasil belajar bertambaha sebesar 0,764. Koefisien regresi tersebut bernili positif, sehingga dapat dikatakan bahwa arah pengaruh variabel kemampuan awal terhadap hasil belajar adalah positif.
\end{abstract}

Kata kunci : kemampuan awal, hasil belajar, IPA, biologi

\begin{abstract}
This study discusses fatherly learning about the initial ability of learning outcomes of Biology participants in grade VIII students of SMP Negeri 1 Kaledupa. This research can help educators in preparing teaching materials for students before starting learning. This type of research used in this study is ex post facto. The population in this study were all class VIII of SMP Negeri 1 Kaledupa with a total of 3 classes, while the sample was obtained by 1 class using purposive sampling. The instrument for collecting data uses test instruments for students' initial abilities as well as for learning outcomes. The results of the research show what is meant by Preliminary Principles on the learning outcomes of Biology Science VIII grade students of SMP Negeri 1 Kaledupa. This is based on the results of hypothesis testing using simple regression analysis obtained significance value of $0.004<0.05$. Also, from a simple regression analysis table supported by an initial ability regression coefficient of 0.764 which is claimed to support every $1 \%$ of the initial ability score, the added learning outcome score is 0.764. This regression coefficient is positive, so it can be agreed that the direction of the effect of the initial ability variable on learning outcomes is positive.
\end{abstract}

Keywords: initial ability, learning outcomes, science, biology 


\section{PENDAHULUAN}

Sekolah sebagai penyelenggara pendidikan formal menjadi salah satu tumpuan dan harapan dalam membentuk sumber daya manusia yang berkualitas, handal, dan unggul. Sekolah sebagai lembaga pendidikan memiliki peranan penting dalam membangun generasi masa depan terletak pada baik tidaknya sistem pendidikan yang dibangun di sekolah. Di sekolah, peserta didik diajarkan berbagai macam ilmu pengetahuan, budi pekerti, serta pendidikan karakter. Salah satu ilmu pengetahuan yang diajarkan sekolah adalah mata pelajaran biologi yang wajib diajarkan di sekolah. Pada mata pelajaran biologi dapat menumbuhkan kemampuan berpikir untuk memecahkan permasalahan dalam kehidupan sehari-hari sudah seharusnya diajarkan secara optimal.

Pada hakekatnya pembelajaran biologi yang diharapkan menghendaki peserta didik memiliki pengetahuan tentang biologi sebagai produk, proses dan sikap. Peserta didik hendaknya menggunakan kemampuan berpikir untuk mendapatkan konsep biologi melalui serangkaian langkah pembelajaran. Peserta didik dapat menyusun konsep-konsep berdasarkan langkah-langkah metode ilmiah. Semua kegiatan tersebut dilakukan oleh peserta didik sendiri sehingga mereka memiliki kompetensi melakukan proses belajar untuk mendapatkan pengetahuan yang diharapkan dapat tercapai dan menghubungkan pengetahuan yang dimiliki dengan kehidupan sehari-hari.

Berdasarkan hal di atas, peneliti melakukan observasi dan wawancara yang dilakukan di SMP Negeri 1 Kaledupa dan dapat diperoleh bahwa lingkungan fisik peserta didik sangat berpengaruh dalam keefektifan proses pembelajaran. Adapun lingkungan fisik yang dimaksud yakni berkenaan dengan aspek alamiah muka bumi seperti sumber daya alam, flora, fauna, iklim dan sebagainya, termasuk pula pelestarian lingkungan yang ada di sekitar kehidupan peserta didik. Dalam kehidupan sehari-hari peserta didik SMP Negeri 1 Kaledupa yang terletak di daerah kepulauan kecil termasuk dalam daerah pedesaan yang menjalani kehidupan yang sederhana. Peserta didik dalam kesehariannya menghabiskan waktu setengah hari di sekolah dengan beberapa aktifitas belajar. Peserta didik yang hidup di lingkungan ini juga sering bersentuhan dengan alam secara langsung. Maka bukanlah hal yang sulit bagi peserta didik untuk mengamati lingkungan alam sekitarnya untuk dijadikan pembelajaran. Sehingga dengan pengalaman peserta didik yang telah ada, maka peserta didik di SMP Negeri 1 Kaledupa dapat lebih mudah memahami dan mengaitkan teori yang telah diperoleh dengan kehidupan nyata peserta didik dalam sehari-hari.

Berdasarkan observasi berupa wawancara langsung yang dilakukan peneliti kepada salah satu guru biologi di SMP Negeri 1 Kaledupa, dapat diketahui bahwa dalam pembelajaran IPA Biologi, aktivitas belajar peserta didik cenderung pasif, artinya pembelajaran berpusat pada guru, walaupun guru telah menggunakan model pembelajaran dan pendekatan yang baik tetapi peserta didik selalu merasa kurang yakin akan kemampuan yang dimilikinya. Diketahui pula bahwa prestasi belajar peserta didik dalam mata pelajaran IPA Biologi masih tergolong kurang maksimal hal ini terbukti masih banyak peserta didik yang remedial ketika ulangan biologi dan nilai hariannya sekitar $80 \%$ tidak mencapai dalam Ketuntasan Belajar Minimal (KBM). Adapun dari wawancara yang dilakukan diketahui bahwa langkah-langkah pembelajaran yang diterapkan oleh guru dalam pembelajaran IPA Biologi adalah pertama, guru menyampaikan kompetensi dan tujuan pembelajaran serta mempersiapkan peserta didik; kedua guru mendemonstrasikan pengetahuan; ketiga, guru

80 IShidik/JBE 4(2) (Agustus 2019) $79-86$ 
membimbing pelatihan yakni memberikan contoh soal lalu memberikan soal yang berkaitan dengan materi; keempat, guru mengecek pemahaman dan memberi umpan balik, yaitu guru bertanya terkait materi yang telah diajarkan; kelima, guru memberikan kesempatan untuk pelatihan lanjutan dan penerapan dengan memberikan tugas rumah.

Wawancara singkat juga diberikan kepada beberapa peserta didik, mereka beranggapan bahwa biologi adalah pelajaran yang lumayan sulit dan tidak begitu menarik. Hal ini karena dalam pembelajaran yang diperoleh, pelajaran IPA Biologi identik dengan bahasa-bahasa latin yang harus mereka hafalkan. Sehingga berdasarkan fenomena tersebut, pelajaran biologi yang seharusnya sangat menarik karena dapat melibatkan alam dalam memahami konsep-konsep biologi, telah bergeser menjadi mata pelajaran yang tidak begitu menarik di mata peserta didik. Hal ini pulalah sehingga dapat mengakibatkan kurangnya hasil belajar peserta didik.

Berdasarkan observasi di atas, terdapat beberapa kendala yang ditemukan yaitu konsep biologi yang seharusnya dipahami peserta didik telah bergeser menjadi hafalan teori semata yang menyebabkan peserta didik kurang aktif dalam proses belajar biologi di kelas, peserta didik mengalami kesulitan di dalam memahami konsep biologi sehingga sulit mengaitkannya dalam kehidupan sehari-hari, serta peserta didik kerap merasa kurang yakin akan kemampuan sendiri. Indikasi dari semua kendala-kendala yang peneliti temukan dalam observasi mengakibatkan hasil belajar IPA Biologi masih tergolong rendah.

Seorang guru tentu selalu berusaha menciptakan pembalajaran yang menarik. Terdapat beberapa hal yang menjadi bahan pertimbangan guru ketika menentukan model pembelajaran dan mengorganisasikan materi pembelajaran. Dalam menentukan materi pembelajaran terkait dengan kehidupan peserta didik, digali dari kehidupan peserta didik, bermanfaat bagi peserta didik dalam memecahkan masalah di lingkungan kehidupannya, sesuai dengan kebutuhan, sehingga materi pembelajaran bermakna secara luas bagi kehidupan peserta didik dan masyarakat di sekitarnya.

Proses pembelajaran yang menarik secara konseptual jika dipandang dari pendekatan kognitif bukan sekedar pemodelan informasi yang berlangsung satu arah saja, melainkan sebagai pemberian makna oleh peserta didik kepada pengalamannya melalui proses asimilasi dan akomodasi yang bermuara kepada pemutakhiran kognitifnya. Kegiatan belajar lebih dipandang dari segi prosesnya dari pada segi perolehan pengetahuan dari fakta-fakta yang ada. Peranan peserta didik dalam konstruktivistik merupakan proses pembentukan pengetahuan. Pembentukan pengetahuan ini harus dilakukan oleh peserta didik itu sendiri. Ia harus aktif melakukan kegiatan, aktif berpikir, menyusun konsep, dan memberi makna tentang hal-hal yang dipelajari. Peserta didik sudah memiliki kemampuan awal sebelum mempelajari sesuatu, sehingga kemampuan awal tersebut dapat digunakan untuk mengkonstruksi pengetahuan baru, walaupun pengetahuan awal tersebut masih sangat sederhana atau tidak sesuai dengan pendapat guru namun setidaknya diterima dan dijadikan dasar pembelajaran dan pembimbingan.

Kemampuan awal merupakan bekal peserta didik dalam menerima materi pelajaran selanjutnya. Kesiapan dan kesanggupan dalam mengikuti pelajaran banyak ditentukan oleh kemampuan awal yang dimiliki oleh peserta didik sehingga kemampuan awal merupakan pendukung keberhasilan belajar. Pelajaran biologi yang diberikan di sekolah telah disusun secara sistematis sehingga untuk masuk pada pokok bahasan lain, kemampuan awal peserta didik pada pokok bahasan yang akan dipelajari dijadikan sebagai bahan pertimbangan untuk

81|Shidik/JBE 4(2) (Agustus 2019) $79-86$ 
mengetahui kemampuan awal peserta didik dengan memberikan tes awal sebelum masuk materi baru. Dalam kegiatan belajar-mengajar setiap materi yang disampaikan hendaknya bisa diserap oleh peserta didik yang berkemampuan awal rendah maupun yang berkemampuan awal tinggi.

Berdasarkan penelitian yang dilakukan oleh Hevriansyah dan Megawanti, diketahui bahwa terdapat pengaruh yang signifikan antara kemampuan awal terhadap hasil belajar matematika peserta didik. Sejalan dengan penelitian di atas, hasil penelitian yang dilakukan oleh Lestari (2017) diperoleh bahwa terdapat pengaruh kemampuan awal terhadap hasil belajar matematika peserta didik.

Peserta didik yang memiliki kemampuan awal tinggi merupakan peserta didik yang telah memiliki pengetahuan dasar tentang materi atau pokok bahasan yang akan dipelajari. Hal ini dapat diketahui berdasarkan hasil tes awal yang diberikan di awal pembelajaran, sebelum memasuki materi pelajaran baru. Tes awal yang diberikan berisi pengetahuanpengetahuan dasar yang telah dimiliki peserta didik dan pengetahuan-pengetahuan yang seharusnya telah diketahui peserta didik dan pengetahuan yang telah ditemukan peserta didik dalam kesehariannya. Sehingga peserta didik yang memiliki kemampuan awal tinggi yakni peserta didik yang memperoleh skor tes awal tinggi, dimana tes ini yang dilakukan sebelum memasuki pelajaran baru. Begitu pula peserta didik yang memiliki kemampuan awal rendah yakni peserta didik yang memperoleh skor tes awal yang lebih rendah dibandingkan peserta didik yang memperoleh skor tinggi. Pada dasarnya seorang guru mengidentifikasi peserta didik yang memiliki kemampuan awal tinggi dan rendah, bertujuan agar guru dapat merancang suatu pembelajaran yang nantinya dapat diserap baik peserta didik yang memiliki kemampuan awal tinggi maupun peserta didik yang memiliki kemampuan awal rendah.

\section{METODE}

Jenis penelitian yang digunakan dalam penelitian ini adalah ex post facto. Menurut Sukardi (2012), penelitian expost facto merupakan penelitian dimana variable-variabel bebas telah terjadi ketika mulai dengan pengamatan variable-variabel terkait dalam suatu penelitian. Jenis penelitian ini dipilih berdasarkan pertimbanhgan peneliti, dimana peneliti bermaksud mencari pengaruh variable bebas terhadap variable terikat. Penelitian ini dilakukan untuk mencari Pengaruh Kemampuan Awal terhadap Hasil Belajar Peserta Didik Kelas VIII SMP Negeri 1 Kaledupa.

Penelitian ini dilaksanakan di SMP Negeri 1 Kaledupa Kabupaten Wakatobi. Populasi dari sampel ini berasal dari seluruh peserta didik Kelas VIII yang terdiri dari 3 kelas dengan jumlah peserta didik 97 orang, sedangkan sampel diperoleh melalui teknik purposive sampling dan diperoleh 1 kelas dengan jumlah peserta didik 32 orang.

Instrumen dalam penelitian ini menggunakan tes kemampuan awal dan tes hasil belajar dengan bentuk tes pilihan ganda dengan masing-masing jumlah soal adalah 19 nomor untuk tes kemampuan awal dan 35 nomor untuk tes hasil belajar IPA Biologi peserta didik.

Data yang diperoleh peneliti kemudian akan dianalisis menggunakan analisisregresi sederhana untuk mengetahui pengaruh variabel bebas terhadap variabel terikat. Hipotesis dalam penelitian ini yaitu:

Ho: Terdapat pengearuh kemampuan awal terhadap hasil belajar IPA Biologi peserta didik kelas VIII SMP Negeri 1 Kaledupa 
H1: Tidak terdapat pengearuh kemampuan awal terhadap hasil belajar IPA Biologi peserta didik kelas VIII SMP Negeri 1 Kaledupa

Dalam menganalisis data, peneliti mengunakan SPSS (Statistical Product and Service Solution) versi 24.

\section{HASIL DAN PEMBAHASAN}

\section{Hasil}

\section{Gambaran kemampuan awal dan hasil belajar peserta didik}

Tabel 1. Hasil Analisis Deskriptif Kemampuan Awal da Hasil Belajar Peserta Didik

\begin{tabular}{|l|r|r|r|r|r|}
\hline & \multicolumn{1}{c|}{ N } & \multicolumn{1}{c|}{ Min } & \multicolumn{1}{c|}{ Max } & \multicolumn{1}{c|}{ Mean } & \multicolumn{1}{c|}{ Sd } \\
\hline Kemampuan awal & 32 & 8.0 & 13.0 & 10.78 & 1.3850 \\
\hline Hasil belajar & 32 & 16.00 & 25.00 & 20.0625 & 2.12417 \\
\hline Valid N (listwise) & 32 & & & & \\
\hline
\end{tabular}

Berdasarkan hasil analisis deskriptif kemampuan awal peserta didik di atas, dari 32 peserta didik memperoleh skor rata-rata sebesar 10,7813 dengan skor minimum 8,00 dan skor maksimum 13,00 dari total skor 19. Sedangkan untuk hasil belajar peserta didik diperoleh rata-rata skor sebesar 20,0625 dengan skor minimum 16,0 dan skor maksimum 25,00 dari total skor 35 .

\section{Uji Prasyarat}

Sebelum melakukan uji hipotesis, peneliti melakukan uji prasyarat terlebih dahulu menggunakan uji normalitas dan uji homogenitas untuk mengetahui apakah data berasal dari data berdistribusi normal atau tidak serta untuk mengetahui apakah data berasal dari varians yang sama.

Tabel 2. Hasil Uji Normalitas

\begin{tabular}{|c|c|c|}
\hline \multicolumn{3}{|c|}{ One-Sample Kolmogorov-Smirnov Test } \\
\hline & & $\begin{array}{c}\text { Unstandardized } \\
\text { Residual }\end{array}$ \\
\hline \multicolumn{2}{|l|}{$\mathrm{N}$} & 32 \\
\hline \multirow{2}{*}{$\begin{array}{l}\text { Normal } \\
\text { Parameters }{ }^{\mathrm{a}, \mathrm{b}}\end{array}$} & Mean & .0000000 \\
\hline & Std. Deviation & 1.84179235 \\
\hline \multirow{3}{*}{$\begin{array}{l}\text { Most } \\
\text { Extreme } \\
\text { Differences }\end{array}$} & Absolute & .131 \\
\hline & Positive & .131 \\
\hline & Negative & -.079 \\
\hline \multicolumn{2}{|l|}{ Test Statistic } & .131 \\
\hline \multicolumn{2}{|c|}{ Asymp. Sig. (2-tailed) } & $.178^{\mathrm{c}}$ \\
\hline
\end{tabular}




\begin{tabular}{|l|}
\hline a. Test distribution is Normal. \\
\hline b. Calculated from data. \\
\hline c. Lilliefors Significance Correction. \\
\hline
\end{tabular}

Berdasarkan hasil uji normalitas diketahui nilai signifikansi 0,178 > 0,05 maka dapat disimpulkan bahwa nilai residual berdistribusi normal.

\section{Uji Hipotesis}

Untuk membuktikan hipotesis, dilakukan uji regresi linear sderhana. Caranya dengan membandingkan tingkat signifikan pada $F_{\text {hitung }}$ dengan taraf signifikasi $(\alpha)$ 0,05 atau 5\%. Dimana jika nilai sig $<0,05$ maka terdapat pengaruh, dan sebalikanya, jika nilai sig $>0,05$ maka tidak terdapat pengaruh.

Tabel 3. Hasil Analisis Regresi Sederhana

\begin{tabular}{|c|c|c|c|c|c|c|}
\hline \multicolumn{2}{|c|}{ Model } & \multicolumn{2}{|c|}{$\begin{array}{c}\text { Unstandardized } \\
\text { Coefficients }\end{array}$} & $\begin{array}{c}\text { Standardized } \\
\text { Coefficients }\end{array}$ & $\mathrm{t}$ & Sig. \\
\cline { 2 - 7 } & B & $\begin{array}{c}\text { Std. } \\
\text { Error }\end{array}$ & Beta & & \\
\hline \multirow{2}{*}{1} & (Constant) & 11.825 & 2.638 & & 4.482 & .000 \\
\cline { 2 - 7 } & Kemampuan Awal & .764 & .243 & .498 & 3.147 & .004 \\
\hline \multicolumn{7}{|c|}{ a. Dependent Variable: Hasil Belajar } \\
\hline
\end{tabular}

Berdasarkan tabel hasil analisis regresi sederhana di atas, diperoleh nilai signifikansi sebesar 0,004 < 0,05 sehingga dapat disimpulkan bahwa terdapat pengaruh kemampuan awal terhadap hasil belajar IPA Biologi peserta didik kelas VIII SMP Negeri 1 Kaledupa. Selain itu, dari tabel di atas diketahui bahwa koefisien regresi kemampuan awal sebesar 0,764 yang menyatakan bahwa setiap penambahan $1 \%$ skor kemampuan awal, maka skor hasil belajar bertambaha sebesar 0,764 . Koefisien regresi tersebut bernili positif, sehingga dapat dikatakan bahwa arah pengaruh variabel kemampuan awal terhadap hasil belajar adalah positif.

\section{Pembahasan}

Berdasarkan hasil analisis data menggunakan analisis regresi linear sederhana, diketahui bahwa terdapat pengaruh kemampuan awal terhadap hasil belajar IPA Biologi peserta didik kelas VIII SMP Negeri 1 Kaledupa yang ditunjukkan diperoleh nilai signifikansi $0,004<0,05$. Kemampuan awal yang dimiliki peserta didik dapat membantu mereka dalam mempersiapkan diri untuk menerima pelajaran. Dengan asumsi bahwa peserta didik sudah punya pengetahuan awal tentang materi yang akan diajarkan. Menurut Suparman (2001) kemampuan awal adalah pengetahuan dan keterampilan yang telah dimiliki siswa sehingga mereka dapat mengikuti pelajaran dengan baik. Kemampuan awal yang dimiliki peserta didik akan diolah didalam kelas oleh guru sehingga nantinya mampu memperoleh hasil belajar yang sesuai dengan harapan dari guru mata pelajaran.

Berdasarkan penelitian yang lakukan oleh Hevriansyah (2016), mengenai pengaruh kemampuan awal terhadap hasil belajar matematika, dari analisis yang dilakukan diperoleh 
bahwa terdapat pengaruh yang signifikan kemampuan awal terhdap hasil belajar matematika. Selain itu, hasil yang sama diperoleh pada penelitian yang dilakukan oleh Astuti (2015), dimana dalam peneltiannya disimpulkan bahwa terdapat pengaruh kemampuan awal terhadap prestasi belajar fisika.

Kemampuan awal merupakan kemampuan yang dimiliki oleh siswa yang diperlukan untuk memperoleh pemahaman baru sehingga diperoleh pemahaman yang lebih baik. Kemampuan awal merupakan prasyarat yang harus dimiliki peserta didik sebelum dimulai pembelajaran, sehingga apabila pembelajaran telah dimulai peserta didik memeiliki bayangan tentang materi yang sedang dipelajari.

Kemampuan awal memiliki peranan yang penting dalam meningkatkan makna dalam mengajar sehingga memudahkan proses-proses internal yang berlangsung dalam diri peserta didik ketika belajar (Uno, 2011). Jika peserta didik mampu mengolah pengetahuan awal yang mereka miliki dengan baik dan dapat dipadukan dengan informasi baru yang mereka peroleh dalam pembelajran, maka hasil belajar yang diperoleh bias menjadi lebih baik lagi, serta memaudahkan peserta didik untuk mengikuti pebelajaran denga materi yang tingkat kesulitannya lebih tinggi lagi.

Oemar Malik (2011) menjelaskan bahwa belajar adalah modifikasi atau memperteguh kelakuan melalui pengalaman. Pendapat lainnya mengatakan bahwa belajar merupakan proses perubahan perilaku dari tidak tau menjadi tahu dan bermanfaat bagi lingkungan maupun individu itu sendiri (Trianto, 2009). Ketika belajar, peserta didik akan mengolah pengalaman yang telah mereka miliki sebelumnya dan atau memanfaatkan pengetahuan awal mereka untuk menemukan kesesuaian antara materi pelajaran yang baru mereka dapatkan saat pembelajaran dengan apa yang sudah mereka pengetahuan awal mereka. Hal ini dapat membantu peserta didik menumbuhkan rasa ingin tahu mereka ketika ternyata pengetahuan awal yang mereka miliki tidak sesuai dengan apa yang disampaikan oleh pendidik.

Sebelum penggunaan strategi proyek dalam suatu kegiatan, siswa sudah memiliki beberapa keterampilan atau menguasai pokok-pokok bahasan yang berkaitan, dengan kata lain siswa harus telah memiliki pengetahuan awal yang berkaitan dengan tugas-tugas yang dikerjakan (Wena, 2012). Hal ini bias dikatakan bahwa kemampuan awal peserta didik marupakan prasyarat yang mestinya sudah dimiliki peserta didik sebelum memulai pembelajaran. Peserta didik yang sudah memiliki kemampuan awal mengenai materi yang disampaikan oleh pendidik akan dapat membantu diri mereka sendiri maupun teman sejawat mereka dalam menerima materi pelajaran dan mengolahnya menjadi satu pemahaman yang baru dan lebih terarah dari sebelumnya.

\section{KESIMPULAN DAN SARAN}

\section{Kesimpulan}

Berdasarkan hasil penelitian yang telah diuraikan di atas, dapat disimpulkan bahwa kemampuan awal peserta didik berpengaruh positif terhadap hasil belajar IPA Biologi peserta didik kelas VIII SMP Negeri 1 Kaledupa. 


\section{Saran}

Saran yang dapat diberikan berdasarkan hasil penelitian ini adalah agar sekiranya pendidik dapat mempertimbangkan kemampuan awal peserta didiknya dalam menyusun bahan ajar yang akan diberikan ke peserta didiknya saat proses belajar mengajar berlangsung, meningat pengetahuan awal dapat mempengaruhi hasil belajar peseta didik.

\section{DAFTAR RUJUKAN}

Astuti, Siwi Puji. (2015). Pengaruh Kemampuan Awal dan Minat Belajar terhadap Prestasi Belajar Fisika. Jurnal Formatif, 5(1), 68-75.

Hamzah B. Uno. (2011). Perencanaan pembelajaran. Jakarta: PT. Bumi Aksara.

Hevriansyah, dkk. (2016). Pengaruh Kemampuan Awal terhdap Hasil Belajar Matematika. JKPM, 2(1), 37-44.

Lestari, Witri. 2017. Pengaruh Kemampuan Awal Matematika dan Motivasi Belajar Terhadap Hasil Belajar Matematika. Jurnal Analisa, 3(1), 76-84.

Made Wena. (2012). Strategi pembelajaran inovatif kontemporer. Jakarta Timur: PT Bumi Aksara.

Oemar Malik. (2011). Kurikulum dan pembelajaran. Jakarta: PT. Bumi Aksara.

Sukardi. 2012. Metode Penelitian Pedidikan. Jakarta: PT. Bumi Aksara.

Trianto. 2009. Mendesain model pembelajaran inovatif-progresif: konsep, landasan, dan implementasinya pada kurikulum tingkat satuan pendidikan (KTSP). Jakarta: Prenada Media Group. 